УДК 378. 147.

Дивак Володимир Валерійович, кандидат педагогічних наук, доцент кафедри інформаційних та комунікаційних технологій ДВНЗ «Університет менеджменту освіти» НАПН України, м. Київ, e-mail: vdivak@yandex.ru

\title{
ПІДГОТОВКА МАЙБУТНІХ ФАХІВЦІВ 3 ПЕДАГОГІКИ ВИЩОЇ ШКОЛИ ЗАСОБАМИ МЕДІАОСВІТНІХ ТЕХНОЛОГІЙ
}

\begin{abstract}
Анотація
Останніми роками медіа-освіта стала популярною і розвивається в багатьох країнах світу. Не оминув цей процес й освіту Україну. У статті аналізується проблема професійної підготовки фахівців з педагогіки вищої школи засобами медіа-освіти. Розкривається специфіка застосування періодичних видань на практичних заняттях із навчального курсу «Педагогіка вищої школи». Адже сучасні медіа відкривають дедалі ширші можливості у сфері освіти і кар'єрного зростання, змінюючи якість повсякденного життя людини. Актуальним для фахівців 3 педагогіки вищої школи є набуття системи знань і практичних умінь для орієнтування в інформаційних потоках сьогодення: пошуку, засвоєння, застосування необхідної інформації, зокрема, медіаінформації; адекватного сприймання, критичного осмислення, звільнення від непотрібної інформації та творчого інтерпретування різноманітної медіа продукції.

Ключові слова: підготовка фахівців, педагогіка вищої школи, медіаосвітні технології, медіаграмотність, медіаінформація.

Постановка проблеми. Приєднання України до Болонського процесу ставить перед українськими вищими навчальними закладами завдання готувати професійних фахівців з педагогіки вищої школи високої кваліфікації з їх подальшим виходом на європейський ринок праці.

Оскільки ми живемо в суспільстві, постійно збагачуваному інформаційними ресурсами, що передбачають широке використання сучасних інформаційних технологій, надання можливості користуватися й обмінюватися інформацією i знаннями, виробляти інформаційні продукти, повною мірою реалізовуючи особистісний потенціал кожної людини щодо професійної кар'єри і якості власного життя, то формування єдиного інформаційного простору висуває певні вимоги до всіх
\end{abstract}


сфер суспільного життя. Зокрема до системних перетворень освітнього процесу i модернізації національної системи освіти. У державних документах, зокрема Державній програмі «Інформаційні та комунікаційні технології в освіті і науці на 2006-2010 рр.», Національній доктрині розвитку освіти, Законі України «Про вищу освіту» наголошується, що входження України до Європейського освітнього простору вимагає якісно нового підходу в підготовці майбутніх фахівців до застосування інформаційно-комунікативних технологій у професійній діяльності.

Отже, одним із стратегічних напрямів підготовки студентів-магістрів 3 педагогіки вищої школи є, передусім, інтегрування медіаосвіти в навчально-виховний процес вищих навчальних закладів для формування медіакультури сучасного фахівця як необхідної умови його професійної культури, професіоналізму та конкурентоспроможності.

Сучасний фахівець повинен володіти високим рівнем професійної культури, що проявляється у здатності творчо мислити, постійній орієнтації на пошук і новизну, використанні науково-технічних знань для розв'язання технічних проблем. Одним 3 елементів даної підготовки $є$ медіа-грамотність особистості. Медіа-грамотність допомагає людині активно використовувати можливості інформаційного поля телебачення, радіо, відео, кінематографу, преси, Інтернету. Щоб підготувати фахівців 3 педагогіки вищої школи, потрібні висококваліфіковані викладачі, які б досконало оволоділи засобами медіа освітніх технологій. Їх основне завдання полягає у навчанні користуватися медіа, що, у свою чергу, є одним з основних завдань вищої школи, де студенти-магістри вчаться розпізнавати способи й форми маніпулятивного впливу медіа, орієнтуються в інформаційному потоці сучасного демократичного суспільства.

В умовах сьогодення необхідною складовою професійної культури майбутнього фахівця з педагогіки вищої школи має стати медіакультура. Як результат медіаосвіти й застосування медіаосвітніх засобів i технологій у професійній підготовці, медіакультура сприятиме формуванню й розвитку медіаосвітніх знань, умінь і навичок роботи з медіаосвітніми засобами фахової інформації та комунікації.

Аналіз досліджень і публікацій. У вітчизняній педагогічній науці дослідження процесу впровадження медіаосвіти з підготовки майбутніх фахівців педагогіки вищої школи перебувають на початковій стадії і потребують, насамперед, розв’язання 
педагогічної проблеми формування медіакультури майбутнього педагога, і зокрема, професійної культури педагога вищої школи нової формації.

Питанням специфіки медіакультури, іiі впливу на суспільство й особистість присвячені праці зарубіжних науковців Д. Белла, М. Маклюена [8] та вітчизняних Л. Найдьонова [9] та інших.

У сучасній освіті формування професійної культури майбутніх фахівців 3 педагогіки вищої школи присвячені праці С. Гончаренка, І. Зязюна, Н. Ничкало, О. Савченко, М. Ярмаченка [11] та інших.

Використання інтерактивних технологій на курсах навчальних дисциплін педагогіки та методики вищої школи досліджували Л. Артемова, Л. Білан, В. Білоус $[5,6,7]$ та інші.

Як зазначається у Законах України «Про освіту», «Про вищу освіту», «Про основні засади розвитку інформаційного суспільства в Україні на 2007-2015 роки» [1, 2, 3], Концепції впровадження медіа освіти в Україні [4] та інших нормативних документах підготовка висококваліфікованого фахівця до його професійної діяльності в умовах розвитку сучасних інформаційно-комунікаційних технологій можливе за умов оснащення освітніх закладів електронними засобами навчання i телекомунікаційними засобами доступу до інформаційно-освітніх ресурсів. Отже, на сучасному етапі найважливішим завданням вищої освіти є підготовка майбутніх фахівців до успішного застосування інформаційно-комунікаційних технологій у професійній діяльності.

Метою статті $є$ дослідження особливостей підготовки фахівців 3 педагогіки вищої школи засобами медіа освітніх технологій.

Виклад основного матеріалу дослідження. Відповідно до Закону України «Про вищу освіту» [1] професійна підготовка магістрів (викладачів педагогіки та методик початкового навчання) здійснюється у вищих навчальних закладах IV рівня акредитації. Програма навчання включає цикл гуманітарних і соціально-економічних дисциплін, природничо-наукову, професійну та практичну підготовку.

Аналіз навчальних посібників із «Педагогіки вищої школи» авторів 3. Курлянда, Р. Хмелюка, А. Семенова [10] дозволяє узагальнити специфіку використання періодичних видань професійно-педагогічної проблематики, відповідно до якого студенти-магістри ознайомлюються 3 філософією освіти; iз 
закономірностями, принципами, формами, засобами, методами організації навчальновиховного процесу у вищій школі; новітніми технологіями й комплексними формами організації навчання; системою науково-дослідної і виховної роботи зі студентами. Вивчення відповідного матеріалу супроводжується опрацюванням періодичних видань 3 актуальних проблем професійно-особистісного розвитку. Попри це, особлива увага звертається на формування педагогічної техніки вчителя, специфіку професійно-педагогічної діяльності викладача вищої школи, педагогічний менеджмент i самоменеджмент. Iз сучасних позицій, за допомогою засобів медіаосвіти, розкриваються вимоги до викладача вищого навчального закладу. Висвітлюються різноманітні аспекти роботи зі студентською молоддю, організація морального, правового, економічного й естетичного виховання. Використання педагогічної преси журналів і газет «Педагогіка вищої школи», «Вища освіта», «Початкове навчання та виховання», «Медіакритика» сприятиме професійнопедагогічній підготовці викладачів вищих навчальних у відділах магістратури, формуванню медіаосвіченого фахівця. Адже, головна мета медійного навчання i виховання полягає в підготовці молоді до критичного сприймання медій, як у вільний час, так і в процесі їхньої професійної підготовки.

У процесі вивчення дисциплін вищої школи (актуальних проблем педагогіки, педагогічних інновацій, педагогіки та психології вищої школи) змістові модулі, які включають теоретичний блок, передбачаються різні види діяльності студентівмагістрів: відвідування лекцій, ведення конспекту, участь у проведенні лекцій на рівні відповідей на проблемні запитання, які часто пов’язані 3 переглядом відео- й аудіофрагментів, на рівні виконання індивідуального завдання дослідницького характеру; і практичний блок - ведення зошита для практичних занять, участь у проведенні занять на рівні відповідей на запитання, письмовий контроль і виконання індивідуальних завдань.

Оскільки однією із складових нинішньої інформаційної цивілізації стали аудіовізуальні технології, що створюють навколо людини щільне інформаційне середовище, то акцент індивідуальних завдання обов'язково передбачають огляд періодичної преси протягом 5-7 хвилин, що впливає на формування всебічної обізнаності в галузі педагогічних нововведень, критичного ставлення до отриманої негативної інформації. На I етапі практичного заняття з педагогіки вищої школи: 
реклама періодичної педагогічної преси. Періодична преса підбирається відповідно до дисципліни, яка вивчається, і теми заняття. Одне із завдань полягає не в кількості поданої інформації, яка звалюється на сучасну молоду людину, а в іiї якості, оскільки в моральному й етико-естетичному планах вона часто $є$ не тільки низькою, а й шкідливою.

На нашу думку, формуванню висококваліфікованого медіакомпетентного викладача вищої школи сприятиме аналіз програм радіо-, кіно-, телебачення, сайтів Інтернету; систематичний перегляд проаналізованих навчально-пізнавальних, особистісно-розвивальних програм, робота в мережі Інтернет 3 метою збагачення корисною інформацією, формування критичного ставлення до негативної інформації. Ознайомлення 3 політикою держави щодо відповідного використання i підпорядкування, для особистої користі, засобів медіаосвіти. Аналіз специфіки роботи директорів найрозвиненіших каналів телебачення для з’ясування особливостей вибору, для транслювання і створення нових програм телебачення. Узагальнення значення медіаосвіти як мотивувального чинника в навчанні й соціалізації.

Однак основне завдання, яке стоїть перед майбутніми викладачами вищих навчальних закладів, - вивчення можливостей Інтернет-ресурсів і їх ефективного застосування, використання електронної пошти для індивідуального пересилання кореспонденції, випуск електронної дошки оголошень, створення посилань на сайти в мережі Інтернет, які можуть бути корисними для майбутніх викладачів ВН3 i відкривають доступ до каталогів бібліотек або на індивідуальні сторінки студентів.

Широко використовуються в навчально-виховному процесі телекомунікації, які сприяють розширенню освітнього простору, його глобалізації, наданню освітніх послуг незалежно від територіальних i національних кордонів. До складу мультимедійних послуг входять телефонія, відеоконференція, Інтернет, дистанційне навчання, огляд відео на запит у режимі «on-line» та ін. Відеоконференція $\epsilon$ комп’ютерною технологією, що дає змогу користувачам, які територіально розміщені в різних місцях, одночасно бачити й чути один одного, обмінюватися інформацією і спільно обробляти їі в інтерактивному режимі. Студенти можуть вільно спілкуватися з викладачами, ставити запитання й відразу отримувати відповіді на них. 
Однак викладачі допускаються помилки в тому, що не виховують у студентів критичного ставлення до інформаційних веб-ресурсів мережі Інтернет. Необізнаність майбутніх учителів, викладачів і неспроможність розв'язати зазначену проблему можна пояснити тим, що вони не отримали належної підготовки щодо використання засобів медіаосвіти.

Навчально-пізнавальна діяльність студентів-магістрів є найрізноманітнішою. Вона охоплює: самостійну підготовку випусків новин; редагування i порівняння текстів, створення програм на телебаченні і радіо; випуск університетських газет, які потім поширюються за допомогою мережі Інтернет; співпрацю студентів-магістрів 3 професійними журналістами; самостійне визначення способів функціонування медіа (за принципом “навчання через діяльність”); інтеграцію медіаосвіти у викладання навчальних предметів (здебільшого гуманітарного профілю) вищої школи; окремі заняття 3 кіномистецтва, телебачення і медіакультури; створення аудіовізуальних матеріалів, їхня критика й аналіз.

Висновки даного дослідження. Питання застосування медіаосвітніх технологій у підготовці майбутніх фахівців 3 педагогіки вищої школи не була предметом комплексних наукових досліджень. У сучасних умовах, коли суспільні вимоги до професійного рівня підготовки майбутніх фахівців 3 педагогіки вищої школи підвищуються, це потребує розроблення сучасних педагогічних підходів до професійної підготовки фахівців - майбутніх викладачів із застосуванням медіаосвітніх технологій.

Отже, у процесі дослідження теоретичних положень стосовно формування медіакультури фахівців з педагогіки вищої школи ми прийшли до висновку, що вища освіта потребує певного переосмислення характеру підготовки сучасних фахівцівпедагогів і може стати середовищем інтегрування медіаосвіти в навчально-виховний процес ВНЗ як необхідної умови його професіоналізму і конкурентоспроможності. Крім того, залучення майбутніх фахівців з педагогіки вищої школи до створення творчих проектів для формування їхньої медіакультури стане більш ефективним за умови використання аудіовізуальних технологій. 


\section{Список використаних джерел}

1. Закон України «Про вищу освіту» №2984-III, із змінами від 19 січня 2010 р. [Електронний pecypc]. http://crl.dsmu.edu.ua/index.php?option=com_content\&task=view\&id=103\&Itemid=50

2. Державна програма “Інформаційні та комунікаційні технології в освіті і науці" на 2006-2010 p. [Електронний ресурс]. - Режим доступу : http://www.chnu.cv.ua/index.php?page=ua/grants/main/933.

3. Закон України «Про основні засади розвитку інформаційного суспільства в Україні на 2007-2015 p. [Електронний ресурс]. - Режим доступу : http://zakon2.rada.gov.ua/laws/show/537-16.

4. Концепція впровадження медіа освіти в Україні [Електронний ресурс]. - Режим доступу : http://www.ispp.org.ua/news_44.htm.

5. Артемова Л. В. Педагогіка і методика вищої школи: інтерактивні технології в курсах навчальних дисциплін [Текст] : навч.-метод. посіб. / Л. В. Артемова. — К. : Кондор, 2008. - 272 c.

6. Білан Л. Л. Методика викладання у вищій аграрній школі : навч. посіб. / Л. Л. Білан — Ніжин : ПП Лисенко, 2010. — 299 с.

7. Білоус В. Т. Основи організації та методики викладання у вищій школі : навч.метод. посіб. / В. Т. Білоус, Л. І. Горюнова, А. В. Цимбалюк, С. Я. Цимбалюк. Ірпінь : Академія ДПС України, 2001. - 146 с.

8. Маклюэн М. Понимание медиа: внешние расширения человека Understanding Media: The Extensions of Man / М. Маклюэн. - М. : Кучково поле, 2007. — 464 с.

9. Найдьонова Л. А. Перспективи розвитку медіаосвіти в контексті болонського процесу: процесуальна модель медіакультури / Л. А. Найдьонова // Болонський процес і вища освіта в Україні та Європі: проблеми й перспективи. — К., 2007. — C. $162-168$.

10.Педагогіка вищої школи : навч. посіб. / [3. Н. Курлянд, Р. І. Хмелюк, А. В. Семенова та ін. ; ра ред. 3. Н. Курлянд]. - К. : Знання, 2005. — 399 с.

11. Педагогіка / за ред. М. Д. Ярмаченка. — К., 1986. 


\section{ПОДГОТОВКА БУДУЩИХ СПЕЦИАЛИСТОВ ПО ПЕДАГОГИКЕ ВЫСШЕЙ ШКОЛЫ СРЕДСТВАМИ МЕДИАОБРАЗОВАТЕЛЬНЫХ ТЕХНОЛОГИЙ}

Дывак Владимир Валерьевич, кандидат педагогических наук, доцент кафедры информационных и коммуникационных технологий, Государственное высшее учебное заведение «Университет менеджмента образования» НАПН Украины, г. Киев, e-mail: vdivak@yandex.ru

\section{Аннотация}

В последние годы медиаобразование стало популярным и развивается во многих странах мира. Не обошел этот процесс и Украину. В статье анализируется проблема профессиональной подготовки специалистов по педагогике высшей школы средствами медиаобразования. Раскрывается специфика применения периодических изданий на практических занятиях из учебного курса "Педагогика высшей школы". Обобщаются особенности изучения спецкурса "Медиаобразование", его роль в формировании высококвалифицированного специалиста высшей школы. Современные медиа открывают все более широкие возможности в сфере образования и карьерного роста, изменяя качество повседневной жизни человека. Высшие учебные заведения уже не могут обойтись без информационных технологий, использования достижений техносферы для решения образовательных заданий, но при этом оставляют без внимания то, которое является не менее важным для общества и содержания собственно процессу образования: ценность гуманитарного знания. Актуальным для специалистов по педагогике высшей школы есть приобретение системы знаний и практических умений для ориентирования в информационных потоках настоящего: поиска, усвоения, применения необходимой информации, в частности, медиаинформации; адекватного восприятия, критического осмысления, освобождения от ненужной информации и творческого интерпретирования разнообразной медиапродукции.

Ключевые слова: подготовка специалистов, педагогика высшей школы, медиаобразовательные технологии, медиаграмотность, медиаинформация. 


\section{PREPARATION OF FUTURE SPECIALISTS ON PEDAGOGICS OF HIGHER SCHOOL BY MEANS OF MEDIAEDUCATIONAL TECHNOLOGIES}

Volodymyr V. Dyvak, PhD (pedagogical sciences), senior lecturer of the Department of information and of communication technologies, State higher educational establishment «University of Educational Management», NAPS of Ukraine, Kyiv, e-mail: vdivak@yandex.ru

\section{Resume}

In recent years mediaeducation became popular and is being developed in many countries of the world. The same process can be observed in Ukraine. In the article the problem of professional preparation of specialists on pedagogics of higher school by means of mediaeducation is analysed. The specific of application of magazines at the practical lessons of educational course "Pedagogics of higher school" is shown. The features of study of the special course "Mediaeducation" are summarized, as well as its role in the formation of highly skilled specialist of higher school. Modern medias open a lot of possibilities in the sphere of education and career development, changing quality of man's everyday life. Higher educational establishments can not exist already without information technologies, usage of achievements of technosphere for the decision of educational tasks, but disregard value of humanitarian knowledge, that is no less important for society and the process of education. Currently important for specialists on pedagogics of higher school is an acquisition of the system of knowledges and practical skills for orientation in the informative streams of nowadays: search, mastering, usage of necessary information, in particular, mediainformation; adequate perception, critical comprehension, liberation from unnecessary information and creative interpretation of various mediaproducts.

Keywords: preparation of specialists, pedagogics of higher school, mediaeducational technologies, medialiteracy, mediainformation. 